\title{
reliquary ghosts of women
}

\author{
Wendy McGrath
}

\section{relique \\ fantômes de femmes}

Relique 1. Corps, fragment du corps d'un saint ou d'un bienheureux... 2. Objet auquel on accorde moralement le plus grand prix comme à un vestige ou à un témoin d'un passé cher. (Petit Robert).

«Relique» de McGraph invite à une méditation sur le son; sur l'articulation de différences phonologiques subtiles; sur les sons qui remplissent l'espace et incitent au mouvement; sur la reconfiguration buccale qui s'effectue lorsqu'on parle, chante, mange, suce, embrasse, etc.; sur la portée musicale vue comme un graphique du son; sur le son comme médium d'échange servant d'intermédiaire entre l'âme et le corps; sur le son comme une note. "Fantômes de femmes" joue de façon similaire avec le tangible et l'intangible, entre "l' incapacité de se passer des fermmes» et «la femme-fantasme». Les poèmes de McGraph nous permettent de discerner, de percevoir les femmes qui sont toujours au travail sans pourtant jamais êtres visibles publiquement.

\section{reliquary}

1.

song knowing somnambulent

desire sleep and dream

un/speakable speak

sing throated space filling

hot coal hesitant snake charming

music photo

graph of sound

mind and body 
2.

suck sugar

soundless and melt sweet

in your mouth

taste melts sweet

in mine

3.

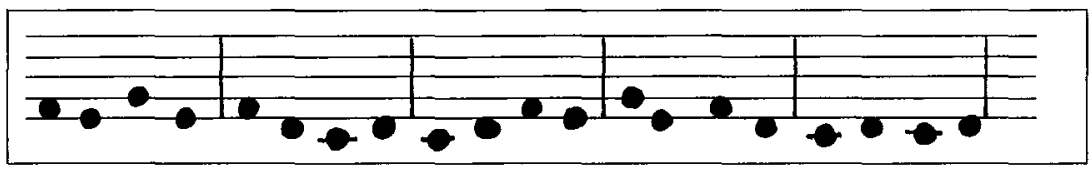

4.

to you je t'aime

I give sounds strange

throat songs

pass to you

words round

smooth

a stone on my tongue

5.

gutteral gutter all breathe from

hold that note

night hold

hold

hold 


\section{ghosts of women}

I.

people coming home

late at night

had seen the road light up

ghost of a woman cross

silent birds fly

motionless trees glow silver

skeptics said

it's only the reflection

of headlights coming

the other way

but after a fire

went through that bush

she was never seen again

II.

a secondwind well after midnight

scrubbing floors

you'll be sorry

if you stay up too late

she heard screeching

outside the door

a fighting cock?

neck hair stood up

tingling/roots yanked

by the sound

she checked the house

to see that everyone

still slept

still dressed 
climbed in beside her husband smell of scrub water still on her hands

III.

femme phantasm

perfume smell at 2 a.m.

grapes of wraith

cold corners

spider crawl nails

spirit hands

catch things that

fall from walls

eager to help

shady voyeurs

women you

can't get rid of 